\title{
Antioxidant and antihemolytic activity of lipid-soluble bioactive substances in avocado fruits
}

Seyed Fazel NABAVI ${ }^{1}$, Seyed Mohammad NABAVI ${ }^{1 *}$, William N. SETZER ${ }^{2}$, Shakoora Alsadat NABAVI ${ }^{3}$, Sharifeh Alsadat NABAVI ${ }^{4}$, Mohammad Ali EBRAHIMZADEH ${ }^{5}$

\author{
${ }^{1}$ Appl. Biotechnol. Res. Cent., \\ Baqiyatallah Univ. Med. Sci., \\ Tehran, Iran, \\ Nabavi208@gmail.com \\ 2 Dep. Chem., Univ. Alabama, \\ Huntsville, Alabama 35899, \\ USA \\ ${ }^{3}$ Dep. Biol., Damghan Branch, \\ Islam. Azad Univ., Damghan, \\ Iran \\ ${ }^{4}$ Fac. Agric., Univ. Birjand, \\ Birjand, Iran \\ ${ }^{5}$ Fac. Pharm., Mazandaran \\ Univ. Med. Sci., Sari, Iran
}

${ }^{*}$ Correspondence and reprints

Received 16 April 2012 Accepted 30 July 2012

Fruits, 2013, vol. 68, p. 185-193 (C) 2013 Cirad/EDP Sciences All rights reserved DOI: $10.1051 /$ fruits/2013066 www.fruits-journal.org

RESUMEN EsPAÑoL, p. 193
Antioxidant and antihemolytic activity of lipid-soluble bioactive substances in avocado fruits.

Abstract - Introduction. Persea americana (avocado) fruit is known to be a rich source of proteins and minerals, as well as vitamins. Although many biological activities have been reported for avocado fruit, far less attention has been paid to the biological properties of its lipid-soluble bioactive substances. The aim of this study was to evaluate the antioxidant and antihemolytic activity of lipid-soluble bioactive compounds of avocado fruit. Materials and methods. Antioxidant and antihemolytic activity of lipid-soluble bioactive compounds of avocado fruit was assessed by employing different methods. Also, the ability of avocado fruit to protect fluorescein against oxidant-induced bleaching was evaluated. Results and discussion. The tested sample showed good antioxidant and antihemolytic activities. There was no significant difference between the reducing power of lipid-soluble bioactive substances in avocado fruits and ascorbic acid $(p<0.05)$. The tested sample showed weak ferrous ion-chelating activity. The sample exhibited moderate hydrogen peroxide scavenging activity, but exhibited good antioxidant activity. Avocado fruit showed very good activity against 2,2'-azobis(2-amidinopropane) dihydrochloride- and hydrogen peroxide-induced hemolysis in erythrocytes. Furthermore, it showed good protective effects against peroxyl radical-induced bleaching in fluorescein. Conclusion. Lipid-soluble bioactive substances of avocado fruit showed good activity in all of the studied models.

Iran Islamic Republic / Persea americana / fruits / lipid peroxidation / nitric oxide / antioxidants / antihemolysis

\section{Activités antioxydante et antihémolytique de substances bioactives liposolubles dans l'avocat.}

Résumé - Introduction. Les fruits de Persea americana, ou avocats, sont connus pour être riches en protéines et minéraux, ainsi qu'en vitamines. Bien que de nombreuses activités biologiques aient été signalées pour ce fruit, beaucoup moins d'attentions n'ont été accordées aux propriétés biologiques de ses substances bioactives liposolubles. L'objectif de notre étude a été d'évaluer l'activité antioxydante et antihémolytique de composés bioactifs liposolubles du fruit de l'avocat. Matériel et méthodes. L'activité antioxydante et antihémolytique des composés bioactifs liposolubles de l'avocat a été évaluée par différents moyens. En outre, la capacité des avocats à protéger la fluorescéine contre le blanchiment induit par un oxydant a été évaluée. Résultats et discussion. L'échantillon étudié a montré de bonnes activités antioxydante et antihémolytique. Il n'y a pas eu de différences significatives entre le pouvoir réducteur des substances bioactives liposolubles des fruits et celui de l'acide ascorbique $(p<0,05)$. L'échantillon testé a montré une faible activité de chélation des ions ferreux et une activité modérée de piégeage du péroxyde d'hydrogène, mais il a présenté une bonne activité antioxydante. Il a révélé une très bonne activité contre le 2,2'-azobis(2-amidinopropane) dihydrochloride et le peroxyde d'hydrogène induisant l'hémolyse dans les érythrocytes. Par ailleurs, il a montré de bons effets protecteurs contre les radicaux péroxyles induisant le blanchiment dans la fluorescéine. Conclusion. Les substances bioactives liposolubles du fruit de l'avocat ont montré une bonne activité dans tous les modèles étudiés.

Iran République islamique / Persea americana / fruits / péroxydation des lipides / oxyde nitrique / antioxydant / antihémolyse 


\section{Introduction}

The role of free radicals in the pathology of many diseases such as cardiovascular, neurodegenerative, cancer, etc., has been well established. Free radical-induced oxidative stress causes serious damage to important biomacromolecules that leads to cell death and then organ dysfunction [1]. Antioxidant therapy is one of the most important and safe ways to prevent oxidative damage. Synthetic antioxidants are very effective but numerous side effects have been reported from them [2]. There has been a recent upsurge in the search for new antioxidants of natural origin. Fruits are of particular interest, because they are rich sources of different classes of antioxidant phytochemicals such as flavonoids, polyphenolic compounds, vitamins, etc. Avocado (Persea americana Mill.) is an oleaginous fruit with high concentrations of monounsaturated fatty acids [3, 4]. Previous studies showed that its fruits are a rich source of carotenoids, B group vitamins, ascorbic acid and tocopherols, and phenols [5-7]. They also contain terpenoids, D-manno-heptulose and $\beta$-sitosterol [8-10]. Numerous biological activities have been reported for its fruit including antioxidative, acetyl CoA carboxylase inhibitory, and antifungal and anticancer activities [3, 11-13].

Henry et al. determined the antioxidant activities of several $\mathrm{C}_{8}-\mathrm{C}_{24}$ saturated and unsaturated fatty acids. They found that most of the unsaturated fatty acids have potent antioxidant activities [14]. Previous studies demonstrated that avocado fruit is a very rich source of fatty acids, especially its lipophilic extract [8]. Also, the lipophilic fraction of avocado fruit is rich in tocopherols and carotenoids, which are known to be potent antihemolytic and antioxidant agents [15-17]. Far less attention has been given to avocado fruit's lipid substances, that may also contribute to antioxidant and antihemolytic properties. In our study, we present the separation of lipid-soluble components from ripe California Hass avocado fruit and an assessment of their antioxidant and antihemolytic activities using different, complementary methods.

\section{Materials and methods}

\subsection{Chemicals}

Ferrozine, linoleic acid, trichloroacetic acid (TCA), 1,1-diphenyl-2-picryl-hydrazyl (DPPH), potassium ferricyanide, fluorescein, 2,2'-azobis(2-amidinopropane) dihydrochloride (AAPH), and hydrogen peroxide were purchased from Sigma Chemicals Co. (St Louis, MO, USA). Gallic acid, quercetin, butylated hydroxyanisole (BHA), ascorbic acid, vitamin E, sulfanilamide, $N$-(1naphthyl)ethylenediamine dihydrochloride, ethylenediaminetetraacetic acid (EDTA) and ferric chloride were purchased from Merck (Darmstadt, Germany). All other chemicals were of analytical grade or purer.

\subsection{Plant materials}

Avocado fruits were collected from Ghaemshahr, Mazandaran, Iran. The fruits were transported to the laboratory and kept at $<4{ }^{\circ} \mathrm{C}$ for $24 \mathrm{~h}$ prior to sample preparation. The fruits were oven-dried at $40{ }^{\circ} \mathrm{C}$ for 5 days. Samples were coarsely ground (2$3 \mathrm{~mm}$ ) before the extraction procedure.

\subsection{Extraction procedure and saponification}

The extraction procedure was performed using the method of Heinonen et al. [5] with slight modifications. All organic solvents used for extraction contained butylated hydroxytoluene $(0.1 \%, \mathrm{w} / \mathrm{v})$ as an antioxidant. The sample $(20 \mathrm{~g})$ was mixed with acetone $(40 \mathrm{~mL})$, homogenized, extracted by triplicate sonication with acetone $(160 \mathrm{~mL})$, and vacuum-filtered. The filtrates were combined and concentrated under vacuum. The combined extract was saponified $(24 \mathrm{~h})$ at $25^{\circ} \mathrm{C}$ using a mixture of potassium hydroxide ( $20 \mathrm{~mL}, 9 \mathrm{~mol} \cdot \mathrm{L}^{-1}$ ) in ethanol (50\%). Ascorbic acid, $0.5 \mathrm{~g}$ (as an antioxidant) was added to the saponification mixture. After $24 \mathrm{~h}$ of saponification, the mixture was diluted with sodium chloride solution (200 mL, 10\%) and carotenoids and vitamin $\mathrm{E}$ were extracted in triplicate with hexane with butylated 
hydroxytoluene (20 mL, $0.1 \%$ in hexane) as an antioxidant. The hexane fractions were combined and evaporated to complete dryness under vacuum.

\subsection{Antioxidant activity}

\subsubsection{1,1-Diphenyl-2-picrylhydrazyl (DPPH) radical scavenging}

The sample $\left(25-400 \mathrm{mg} \cdot \mathrm{mL}^{-1}\right)$ was added, at an equal volume, to solution of 1,1-diphenyl-2-picrylhydrazyl (100 mM in methanol). Reactions were incubated for $15 \mathrm{~min}$ at room temperature and then were recorded at $517 \mathrm{~nm}$. The experiment was repeated three times. Ascorbic acid, butylated hydroxytoluene and quercetin were used as standard controls. IC $_{50}$ values denote the concentration that is scavenging $50 \%$ of free radicals [2].

\subsubsection{Reducing power}

The reducing power of the extract was determined using the method of Yen and Chen [18]. The sample $\left(100-800 \mathrm{mg} \cdot \mathrm{mL}^{-1}, 2.5 \mathrm{~mL}\right)$ was mixed with phosphate buffer $(2.5 \mathrm{~mL}$, $0.2 \mathrm{M}, \mathrm{pH}$ 6.6) and potassium ferricyanide $(2.5 \mathrm{~mL}, 1 \%)$. Reaction mixtures were incubated at $50{ }^{\circ} \mathrm{C}$ for $20 \mathrm{~min}$. To stop the reaction, trichloroacetic acid $(10 \%, 2.5 \mathrm{~mL})$ was added to the mixtures, which were then centrifuged at $1000 \mathrm{~g}$ for $10 \mathrm{~min}$. The upper layer of solution $(2.5 \mathrm{~mL})$ was mixed with distilled water $(2.5 \mathrm{~mL})$ and $\mathrm{FeCl}_{3}(0.1 \%$, $0.5 \mathrm{~mL}$ ), and measured at $700 \mathrm{~nm}$. Increased absorbance of the reaction mixture indicated increased reducing power. Ascorbic acid was used as a positive control.

\subsubsection{Metal chelating}

The activity of the sample to chelate iron ions was estimated by the method of Dinis et al. [19]. The sample (100-1600 $\mu \mathrm{g} \cdot \mathrm{mL}^{-1}$, $1 \mathrm{~mL}$ ) was added to a solution of $\mathrm{FeCl}_{2}$ ( $2 \mathrm{mM}, 0.05 \mathrm{~mL}$ ). Ferrozine $(5 \mathrm{mM}, 0.2 \mathrm{~mL}$ ) was added to initiate the reaction and the mixture was shaken vigorously and left standing at room temperature for $10 \mathrm{~min}$. Absorbance of the solutions was then measured at $562 \mathrm{~nm}$. $\mathrm{Na}_{2}$ EDTA was used as a positive control.

\subsubsection{Nitric oxide scavenging}

Sodium nitroprusside $(10 \mathrm{mM})$, in phosphate-buffered saline, was mixed with different concentrations of sample (50$800 \mu \mathrm{g} \cdot \mathrm{mL}^{-1}$ ), and incubated at room temperature for $150 \mathrm{~min}$. After the incubation period, $0.5 \mathrm{~mL}$ of Griess reagent ( $1 \%$ sulfanilamide, $2 \%$ phosphoric acid and $0.1 \% \mathrm{~N}$ (1-naphthyl)ethylenediamine dihydrochloride) was added. The absorbance was measured at $546 \mathrm{~nm}$. Quercetin was used as a positive control [20].

\subsubsection{Hydrogen peroxide scavenging}

The sample $\left(2 \mathrm{~mL}, \quad 0.1-1 \mathrm{mg} \cdot \mathrm{mL}^{-1}\right)$ was added to a hydrogen peroxide solution $(0.6 \mathrm{~mL}, 40 \mathrm{mM})$ in phosphate buffer ( $\mathrm{pH} 7.4$ ). The absorbance of the sample at $230 \mathrm{~nm}$ was measured after $10 \mathrm{~min}$ against a blank solution containing phosphate buffer without hydrogen peroxide and extracts. Ascorbic acid and quercetin were used as standards [21].

\subsubsection{Hemoglobin-induced linoleic acid system}

A reaction mixture $(2 \mathrm{~mL})$ containing $100 \mu \mathrm{L}$ of the sample $\left(100-400 \mu \mathrm{g} \cdot \mathrm{mL}^{-1}\right)$, linoleic acid emulsion $\left(1 \mathrm{mmol} \cdot \mathrm{L}^{-1}\right)$, phosphate buffer ( $40 \mathrm{mmol} \cdot \mathrm{L}^{-1}, \mathrm{pH}$ 6.5) and hemoglobin suspension $(0.0016 \%)$ was incubated at $37^{\circ} \mathrm{C}$ for $45 \mathrm{~min}$. After the incubation, hydrochloric acid in ethanol $(0.6 \%, 2.5 \mathrm{~mL})$ was added to stop the lipid peroxidation. The amount of peroxide value was measured in triplicate using the thiocyanate method by reading the absorbance at $480 \mathrm{~nm}$ after reaction with $\mathrm{FeCl}_{2}$ $\left(0.02 \mathrm{~mol} \cdot \mathrm{L}^{-1}, 100 \mu \mathrm{L}\right)$ and ammonium thiocyanate $\left(0.3 \mathrm{~g} \cdot \mathrm{mL}^{-1}, 50 \mu \mathrm{L}\right)$. Ascorbic acid was used as a positive control [2].

\subsection{Antihemolytic activity}

\subsubsection{Protection against hydrogen peroxide-induced hemolysis}

Male rats in the body weight range of 180-220 g were housed in individual polypropylene cages and had free access to 
food and water. The animals were fed with a standard diet. The animals were anesthetized with ketamine $\left(60 \mathrm{mg} \cdot \mathrm{kg}^{-1}\right)$ and xylazine $\left(5 \mathrm{mg} \cdot \mathrm{kg}^{-1}\right)$ given intraperitoneally. Blood samples were collected via retroorbital puncture in plain plastic tubes. Erythrocytes were isolated and stored according to the method described by Alinezhad et al. [2]. Different concentrations of the sample $(0.5 \mathrm{~mL})$ were added to erythrocyte suspension $(4 \%, 2 \mathrm{~mL})$ and the volume was made up to $5 \mathrm{~mL}$ with saline buffer. Reaction mixtures were incubated for $5 \mathrm{~min}$ at room temperature and then $0.5 \mathrm{~mL}$ of $\mathrm{H}_{2} \mathrm{O}_{2}$ solution in saline buffer was added to induce hemolysis. After incubation (240 min) at room temperature, the reaction mixture was centrifuged at $250 \mathrm{~g}$ for $10 \mathrm{~min}$ and the extent of hemolysis was determined by measuring the absorbance at $540 \mathrm{~nm}$ corresponding to hemoglobin liberation [2].

\subsubsection{2,2'-Azobis(2-amidinopropane) dihydrochloride-induced hemolysis assay}

Blood was obtained from male rats by cardiac puncture and collected into heparinized tubes. Blood was centrifuged $(3000 \mathrm{rpm}$, $10 \mathrm{~min}, 4^{\circ} \mathrm{C}$ ) and plasma and the buffy coat were then separated. Erythrocytes were washed with phosphate buffered saline ( $\mathrm{pH} 7.4)$, and then re-suspended to the desired hematocrit level. In order to induce free radical oxidation of the erythrocytes, aqueous peroxyl radicals were produced by thermal decomposition of 2,2'-azobis(2-amidinopropane) dihydrochloride (dissolved in phosphate buffered saline, final concentration $50 \mathrm{mM}$ ). To assess the protective effects of the sample against 2,2'-azobis(2-amidinopropane) dihydrochloride-induced oxidation of erythrocytes, an erythrocyte suspension ( $2 \%$ hematocrit) was pre-incubated with the lipid-soluble bioactive substances of avocado fruits $\left(100-800 \mu \mathrm{g} \cdot \mathrm{mL}^{-1}\right)$ at $37{ }^{\circ} \mathrm{C}$ for $30 \mathrm{~min}$, followed by incubation with and without 2,2'-azobis(2-amidinopropane) dihydrochloride $(50 \mathrm{mM})$. The reaction mixture was shaken slowly while being incubated $\left(4 \mathrm{~h}\right.$, at $\left.37^{\circ} \mathrm{C}\right)$. Hemolysis was evaluated spectrophotometrically by employing the method of Ko et al. [21]. Briefly, aliquots of the reaction mixture were taken out at each hour of the $4 \mathrm{~h}$ of incubation, diluted with normal saline, and centrifuged (6000 rpm, $10 \mathrm{~min}$ ) to isolate the erythrocytes. The hemolysis percentage was evaluated by measuring the absorbance at $545 \mathrm{~nm}$ of the supernatant (A) and compared with that of complete hemolysis (B) by treating an aliquot with the same volume of the reaction mixture with distilled water. The hemolysis percentage was calculated using the formula: $[(\mathrm{A} / \mathrm{B}) \times 100]$.

\subsubsection{The protection of fluorescein against oxidant-induced bleaching}

Fluorescein $(2 \mu \mathrm{M})$ in phosphate buffer (100 mM, pH 7.4) was combined, in the absence or presence of the tested samples, with oxidants, namely 2,2'-azobis(2-amidinopropane) dihydrochloride $(10 \mathrm{mM})$, in a final volume of $2 \mathrm{~mL}$. The fluorescence of each sample was examined at the excitation/emission wavelengths of $480 \mathrm{~nm} /$ $514 \mathrm{~nm}$ after $60 \mathrm{~min}$ of incubation with $2,2^{\prime}$ azobis(2-amidinopropane) dihydrochloride at $37^{\circ} \mathrm{C}$. The results were analyzed in a way analogous to that presented by Kohri et al. [22] by plotting $\left[\left(\Delta \mathrm{F} / \Delta \mathrm{F}_{\mathrm{O}}\right)-1\right] v s$. the concentration of the antioxidant, where $\Delta \mathrm{F}$ is the decrease in fluorescence induced by an oxidant in the presence of a given concentration of that antioxidant, and $\Delta \mathrm{F}_{\mathrm{O}}$ is the decrease in fluorescence induced by the same amount of the oxidant in the absence of an antioxidant.

\subsection{Statistical analysis}

Experimental results are expressed as means \pm standard deviation. All measurements were in triplicate. The data were analyzed by an analysis of variance $(p<0.05)$ and the means separated by Duncan's multiple range tests. The $\mathrm{IC}_{50}$ values were calculated from linear regression analysis.

\section{Results and discussion}

In scavenging of 1,1-diphenyl-2-picrylhydrazyl radical activity, the lipid-soluble bioactive substances of avocado fruits showed good activity $\left[\mathrm{IC}_{50}=(255.2 \pm 8.6) \mathrm{mg} \cdot \mathrm{mL}^{-1}\right]$. 
$\mathrm{IC}_{50}$ values for standard antioxidants, i.e., quercetin, ascorbic acid and butylated hydroxyanisole, were $[(5.0 \pm 0.1),(5.2 \pm 0.2)$ and $(53.9 \pm 3.1)] \mathrm{mg} \cdot \mathrm{mL}^{-1}$, respectively. Lipid-soluble polyphenolic compounds of avocado fruits may be responsible for its good scavenging of 1,1-diphenyl-2-picrylhydrazyl radical. It has been suggested that electron-donating compounds can quench 1,1-diphenyl-2-picrylhydrazyl radicals via either hydrogen- or electron-donation mechanisms and change in the color of reaction mixtures from violet to yellow [2]. In the reducing power assay, lipid-soluble electron-donating compounds in the avocado fruits can reduce $\mathrm{Fe}^{3+}$ to $\mathrm{Fe}^{2+}$. Perl's Prussian blue color induced by the $\mathrm{Fe}^{2+}$ complex can be observed by determining the absorbance of samples at $700 \mathrm{~nm}$ [2]. An increase in absorbance of the samples at $700 \mathrm{~nm}$ indicates an increase in reducing power activity of lipid-soluble bioactive substances of avocado fruits (figure 1).

Ascorbic acid has better reducing power activity than avocado fruit samples. Nitric oxide radical is produced by sodium nitroprusside in physiological condition and interacts with singlet oxygen, leading to production of nitrite ions which can be evaluated via Griess reagent. Scavengers of nitric oxide radicals compete with singlet oxygen, leading to diminished production of nitrite ions. The $\mathrm{IC}_{50}$ for nitric oxide radical scavenging of lipid-soluble bioactive substances of avocado fruits was (375.5 \pm 11.7) $\mathrm{mg} \cdot \mathrm{mL}^{-1}$. Although quercetin, a natural antioxidant, exhibits potent nitric oxide scavenging activity $\left[\mathrm{IC}_{50}=(17.0 \pm 0.0) \mu \mathrm{g}\right.$. $\mathrm{mL}^{-1}$ ], it has been reported to exhibit carcinogenic activity [23]. Nitric oxide radical plays an important role in initiation or progression of several diseases such as inflammation, cancer, atherosclerosis, etc. [2] Therefore, natural antioxidants with potent nitric oxide scavenging activity may be of interest in protection and/or prevention of oxidative damage.

Lipid-soluble bioactive substances of avocado fruits exhibited weak iron-chelating ability $\left(40.2 \%\right.$ at $\left.1600 \mu \mathrm{g} \cdot \mathrm{mL}^{-1}\right)$. Ethylenediaminetetraacetic acid showed very good activity $\left[\mathrm{IC}_{50}=(18.0 \pm 0.5) \mu \mathrm{g} \cdot \mathrm{mL}^{-1}\right]$. Iron chelation can serve to remove tissue iron via

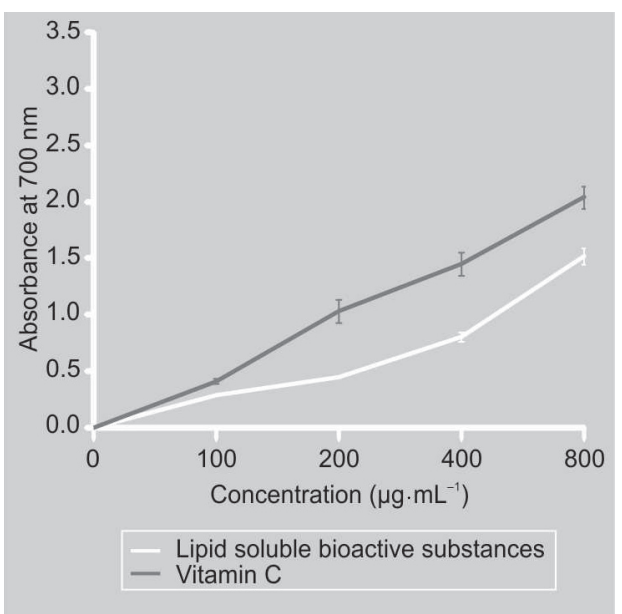

Figure 1.

An increase in absorbance of the samples at $700 \mathrm{~nm}$ indicates an increase in reducing power activity of lipidsoluble bioactive substances of avocado fruits. Vitamin $\mathrm{C}$ used as positive control. formation of soluble, stable complexes that can be excreted in the feces and/or urine. Treatment with chelating agents is one of the most important methods of decreasing iron in iron-overloaded tissues and so improving life quality and overall survival in some diseases such as thalassemia major [24]. In recent years, much attention has been paid to searching for iron-chelating natural compounds with reduced side effects [25]. Many scientific reports have shown that ironchelating agents and hydroxyl radical scavengers can protect against acute renal failure, especially nephrotoxicity induced by aminoglycoside antibiotics [26]. In our work, the method of Dinis et al. [19] was used to evaluate ferrous ion chelation. Ferrozine can quantitatively form complexes with $\mathrm{Fe}^{2+}$. In the presence of iron-chelating agents, the ferrozine $/ \mathrm{Fe}^{2+}$ complex formation is diminished, with a resulting decrease in the red color of the ferrozine complex. In the iron chelation assay, lipid-soluble bioactive substances of avocado fruits and ethylenediaminetetraacetic acid impeded the formation of the ferrozine $/ \mathrm{Fe}^{2+}$ complex, suggesting that the lipid-soluble bioactive substances in avocado fruits have iron-chelating ability and capture iron ions in competition with ferrozine.

Lipid-soluble bioactive substances of avocado fruits show hydrogen peroxide scavenging in a dose-dependent manner. The $\mathrm{IC}_{50}$ of hydrogen peroxide scavenging activity was $(478.8 \pm 16.3) \mathrm{mg} \cdot \mathrm{mL}^{-1}$. The 
Figure 2.

Antioxidant activity of the avocado sample against hemoglobin-induced lipid peroxidation. Vitamin $\mathrm{C}$ used as positive control.

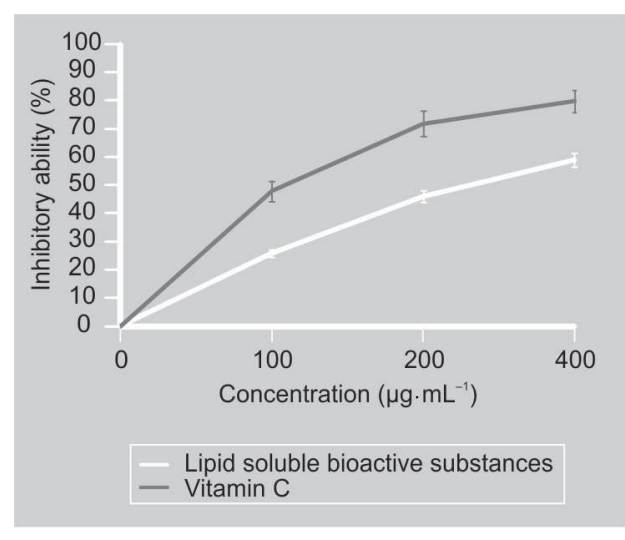

$\mathrm{IC}_{50}$ values for ascorbic acid and quercetin were $[(21.4 \pm 1.1)$ and $(52.0 \pm 2.6)] \mathrm{mg}$. $\mathrm{mL}^{-1}$, respectively. The hydrogen peroxide scavenging activity of the tested sample may be correlated with phenolic compounds and/or other lipid-soluble bioactive natural compounds which can donate electrons to hydrogen peroxide, reducing it to water [2]. Hydrogen peroxide itself is not very reactive, but it can increase hydroxyl radical production in cells and tissues, resulting in cytotoxicity $[20,27]$. The tested sample did show good activity in the hemoglobin-induced linoleic acid emulsion system (figure 2).

Erythrocytes are major targets for free radical assail due to the presence of both high membrane concentration of polyunsaturated fatty acids and the oxygen convey associated with redox active hemoglobin, which are influential promoters of free radicals. Specially, linoleic acid and arachidonic acid are targets of lipid peroxidation [28] The inhibition of lipid peroxidation by antioxidants may be due to their free radical scavenging activities. Lipid peroxidation is indirectly initiated by superoxide because superoxide anion acts as a precursor of singlet oxygen and hydroxyl radicals [20, 29] Hydroxyl radicals assail membrane lipids via removal of hydrogen atoms, which induces lipid peroxidation. The antihemolytic activity of the sample was tested and it was found that it has no harmful effects on erythrocytes. The $\mathrm{IC}_{50}$ of antihemolytic activity was $(395.5 \pm 13.0) \mathrm{mg} \cdot \mathrm{mL}^{-1}$ vs. ascorbic acid $\left[(235.0 \pm 9.1) \mu \mathrm{g} \cdot \mathrm{mL}^{-1}\right)$. Previous scientific reports showed correlation between antihemolytic activity and polyphenolic contents, and good antihemolytic activity may be the result of high concentrations of lipidsoluble polyphenolic compounds [30]. In physiological conditions, 2,2'-azobis(2amidinopropane) dihydrochloride decomposes stably to produce peroxyl radicals. These peroxyl radicals cause polyunsaturated lipid oxidation in erythrocyte membranes to induce lipid peroxidation. As a result of lipid peroxidation, erythrocyte membranes endure injury quickly and lose their integrity, which leads to the release of hemoglobin or hemolysis [31]. Natural compounds with antioxidant activity have been shown to protect erythrocytes against 2,2'azobis(2-amidinopropane) dihydrochlorideinduced hemolysis. Banerjee et al. have shown that treating erythrocytes with polyphenolic compounds protects them against 2,2'-azobis(2-amidinopropane) dihydrochloride-induced hemolysis, as evidenced by reduced release of hemoglobin and formation of thiobarbituric acid-reactive substances [31]. Additionally, Zhu et al. have shown that treating rat erythrocytes with cocoa extract containing flavonoids inhibits hemolysis induced by 2,2'-azobis(2-amidinopropane) dihydrochloride in vitro [32]. Furthermore, these reports attributed the antihemolytic activity of these plant-derived compounds to their antioxidant property. Our results suggest that lipid-soluble bioactive substances of avocado fruits can inhibit hemolysis by altering the cell membrane of erythrocytes, rather than by directly scavenging peroxyl radicals $\left[\mathrm{IC}_{50}=(313.0 \pm\right.$ 11.5)]. Lipid-soluble bioactive substances of avocado fruits effectively protected fluorescein against peroxyl radicals derived from the commonly used azo initiator, 2,2'-azobis(2-amidinopropane) dihydrochloride-induced bleaching. Treating erythrocytes with oxidants causes hemolysis, which can be easily observed turbidimetrically in a plate reader, and which is protected by antioxidants. The results of this assay system are consistent with the sample having protected erythrocytes against 2,2'-azobis(2-amidinopropane) dihydrochloride-induced hemolysis (figure 3). 


\section{Conclusions}

This study demonstrates that the lipid-soluble bioactive-rich fraction of avocado fruits has antioxidant and antihemolytic activities. Extracts show different activity in ex vivo and in vitro models. Future studies on in vivo antioxidant and toxicological effects and/or using these substances in clinical studies are necessary. According to the results of the present study, these avocadoderived substances can serve as a starting point for further research and applications in the preparation of natural pharmaceuticals or herbal formulations.

\section{References}

[1] Nabavi S.M., Nabavi S.F., Eslami S. Moghaddam A. ., In vivo protective effects of quercetin against sodium fluoride-induced oxidative stress in the hepatic tissue, Food Chem. 132 (2012) 931-935.

[2] Alinezhad H., Baharfar R., Zare M., Azimi R., Nabavi S.F., Nabavi S.M., Biological activities of ethyl acetate extract of different parts of Hyssopus angustifolius, Pharm. Biol. 50 (2012) 1062-1066.

[3] Lu Q.Y., Arteaga J.R., Zhang Q., Huerta S., Go V.L.W., Heber D., Inhibition of prostate cancer cell growth by an avocado extract: role of lipid-soluble bioactive substances, J. Nutr. Biochem. 16 (2005) 23-30.

[4] Osuna-Garcia J.A., Doyon G., Salazar-Garcia S., Goenaga R., Gonzalez-Duran I.J.L., Effect of harvest date and ripening degree on quality and shelf life of Hass avocado in Mexico, Fruits 65 (2010) 367-375.

[5] Heinonen M.I., Ollilainen V., Linkola E.K., Varo P.T., Koivistoinen P.E., Carotenoids in Finnish foods: vegetables, fruits, and berries, J. Agric. Food Chem. 37(1989) 655-659.

[6] Slater G.G., Shankman S., Shepherd J.S., Alfin-Slater R.B., Seasonal variation in the composition of California avocados, J. Agric. Food Chem. 23 (1975) 468-474.

[7] Vinson J.A., Su X., Zubik L., Bose P., Phenol antioxidant quantity and quality in foods: fruits, J. Agric. Food Chem. 49 (2001) 53155321.

[8] Moreno A.O., Dorantes L., Galindez J., Guzman R.I., Effect of different extraction methods on fatty acids, volatile compounds,

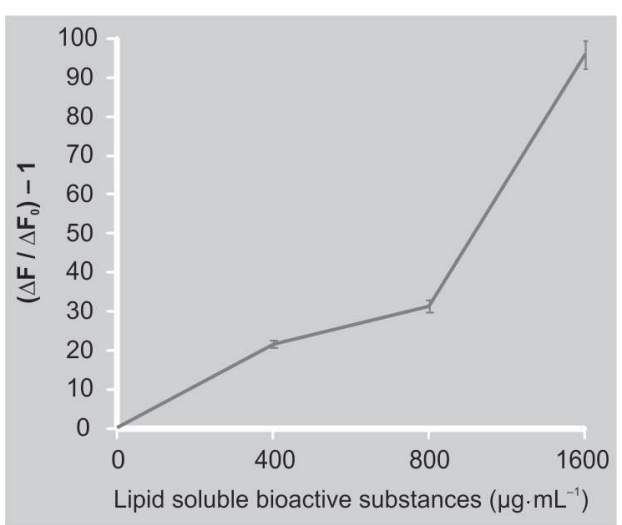

Figure 3.

The protective effect of the lipid-soluble bioactive substances against 2,2'azobis(2-amidinopropane) dihydrochloride-induced fluorescein bleaching. $\Delta \mathrm{F}$ is the decrease in fluorescence induced by an oxidant in the presence of a given concentration of that antioxidant, and $\Delta \mathrm{F}_{0}$ is the decrease in fluorescence induced by the same amount of the oxidant in the absence of an antioxidant. and physical and chemical properties of avocado (Persea americana Mill.) oil, J. Agric. Food Chem. 51 (2003) 2216-2221.

[9] Shaw P.E., Wilson C.W., Knight R.J., Highperformance liquid chromatographic analysis of D-manno-heptulose, perseitol, glucose, and fructose in avocado cultivars, J. Agric. Food Chem. 28 (1980) 379-462.

[10] Duester K.C., Avocado fruit is a rich source of beta-sitosterol, J. Am. Diet. Assoc. 101 (2001) 404-405.

[11] Kim O.K., Murakami A., Nakamura Y., Takeda N., Yoshizumi H., Ohigashi H., Novel nitric oxide and superoxide generation inhibitors, persenone $A$ and $B$, from avocado fruit, J. Agric. Food Chem. 48 (2000) 1557-1563.

[12] Hashimura H., Ueda C., Kawabata J., Kasai T., Acetyl-CoA carboxylase inhibitors from avocado (Persea americana Mill.) fruits, Biosci. Biotechnol. Biochem. 65 (2001) 1656-1658.

[13] Domergue F., Helms G.L., Prusky D., Browse J., Antifungal compounds from idioblast cells isolated from avocado fruits, Phytochemistry 54 (2000) 183-189.

[14] Henry G.E., Momin R.A., Nair M.G., Dewitt D.L., Antioxidant and cyclooxygenase activities of fatty acids found in food, J. Agric. Food Chem. 50 (2002) 2231-2234.

[15] Niki E., Noguchi N., Dynamics of antioxidant action of vitamin E, Acc. Chem. Res. 37 (2004) 45-51.

[16] Wang F., Wang T., Lai J., Li M., Zou C., Vitamin $E$ inhibits hemolysis induced by hemin as a membrane stabilizer, Biochem. Pharmacol. 71 (2006) 799-805. 
[17] Sarkar A., Bishayee A., Chatterjee M., Betacarotene prevents lipid peroxidation and red blood cell membrane protein damage in experimental hepatocarcinogenesis, Can. Biochem. Biophys. 15 (1995) 111-125.

[18] Yen G.C., Chen H.Y., Antioxidant activity of various tea extracts in relation to their antimutagenicity, J. Agric. Food Chem. 43 (1) (1995) 27-32.

[19] Dinis T.C.P., Madeira V.M.C., Almeida L.M., Action of phenolic derivates (acetoaminophen, salycilate and 5-aminosalycilate) as inhibitors of membrane lipid peroxidation and as peroxyl radical scavengers, Arch. Biochem. Biophys. 315 (1994) 161-169.

[20] Mandal S., Hazra B., Sarkar R., Biswas S., Mandal N., Assessment of the antioxidant and reactive oxygen species scavenging activity of methanolic extract of Caesalpinia crista leaf, Evid. Based Complement. Altern. Med. (2011) art no. 173768.

[21] Ko F.N., Hsiao G., Kuo Y.H., Protection of oxidative hemolysis by demethyldiisoeugenol in normal and beta-thalassemic red blood cells, Free Rad. Biol. Med. 22 (1997) 215-222.

[22] Kohri S., Fujii H., Oowada S., Endoh N., Sueishi Y., Kusakabe M., Shimmei M., Kotake Y., An oxygen radical absorbance capacity-like assay that directly quantifies the antioxidant's scavenging capacity against AAPH-derived free radicals, Anal. Biochem. 386 (2009) 167-171.

[23] Dunnik J.K., Hailey J.R., Toxicity and carcinogenicity studies of quercetin, a natural component of foods, Fundam. Appl. Toxicol. 19 (1992) 423-431.

[24] Hebbel R.P., Leung A., Mohandas N., Oxidation-induced changes in microheological properties of the red cell membrane, Blood 76 (1990) 1015-1022.
[25] Grazul M., Budzisz E., Biological activity of metal ions complexes of chromones, coumarins and flavones, Coord. Chem. Rev. 253 (2009) 2588-2598.

[26] Nabavi S.F., Nabavi S.M., Moghaddam A.H., Naqinezhad A., Bigdellou R., Mohammadzadeh S., Protective effects of Allium paradoxum against gentamicininduced nephrotoxicity in mice, Food Funct. 3 (2012) 28-29.

[27] Hazra B., Biswas S., Mandal N., Antioxidant and free radical scavenging activity of Spondias pinnata, BMC Complement. Altern. Med. 8 (2008) 63.

[28] Nabavi S.F., Nabavi S.M., Abolhasani F., Moghaddam A.H., Eslami S., Cytoprotective effects of curcumin on sodium fluorideinduced intoxication in rat erythrocytes, Bull. Environ. Contam. Toxicol. 88 (2012) 486-490.

[29] Nabavi S.F., Moghaddam A.H., Eslami S., Nabavi S.M., Protective effects of curcumin against sodium fluoride-induced toxicity in rat kidneys, Biol. Trace. Elem. Res. 145 (2012) 369-374.

[30] Chaudhuri S., Banerjee A., Basu K., Sengupta B., Sengupta P.K., Interaction of flavonoids with red blood cell membrane lipids and proteins: Antioxidant and antihemolytic effects, Int. J. Biol. Macromol. 41 (2007) 42-48.

[31] Banerjee A., Kunwar A., Mishra B., Priyadarsini K.I., Concentration dependent antioxidant/pro-oxidant activity of curcumin studies from AAPH induced hemolysis of RBCs, Chem. Biol. Interact. 174 (2008) 134139.

[32] Zhu Q.Y., Holt R.R., Lazarus S.A., Orozco T.J., Keen C.L., Inhibitory effects of cocoa flavanols and procyanidin oligomers on free radical-induced erythrocyte hemolysis, Exp. Biol. Med. 227 (2002) 321-329. 


\section{Actividades antioxidante y antihemolítica de las sustancias bioactivas lipo- solubles del aguacate.}

Resumen - Introducción. Las frutas de Persea americana, o aguacates, son conocidas por ser ricas tanto en proteínas y minerales como en vitaminas. Aunque ya se habían señalado numerosas actividades biológicas de esta fruta, se había prestado mucho menos atención a las propiedades biológicas de sus sustancias bioactivas liposolubles. El objetivo de nuestro estudio fue evaluar la actividad antioxidante y antihemolítica de los compuestos bioactivos liposolubles de la fruta del aguacate. Material y métodos. La actividad antioxidante y antihemolítica de los compuestos bioactivos liposolubles del aguacate se evaluó a través de distintos medios. Se evaluó asimismo la capacidad de los aguacates para proteger la fluoresceína contra el blanqueamiento inducido por un oxidante. Resultados y métodos. La muestra estudiada demostró unas actividades antioxidante y antohemolítica positivas. No se registraron diferencias significativas entre el poder reductor de las sustancias bioactivas liposolubles de las frutas frente al del ácido ascórbico $(p<0,05)$. La muestra del ensayo presentó una actividad débil de quelación de los iones ferrosos y una actividad moderada de captura del peróxido de hidrógeno, pero, en cambio, presentó una buena actividad antioxidante. Presentó una actividad muy buena contra el dihidrocloruro de 2,2'-azobis (2-amidinopropano) y el peróxido de hidrógeno, que inducen la hemólisis de los eritrocitos. Además, demostró contar con buenos efectos protectores contra los radicales peroxilos, que inducen el blanqueamiento de la fluoresceína. Conclusion. Las sustancias bioactivas liposolubles de la fruta del aguacate presentaron una buena actividad en todos los modelos estudiados.

Iran República Islámica / Persea americana / frutas / peroxidación lipídica / óxido nítrico / antioxidantes / antihemólisis 